\title{
A New Domain for Public Speech: Opening Public Spaces Online
}

\author{
Stacey D. Schesser $\dagger$
}

\section{INTRODUCTION}

The Internet has galvanized a new community of public speakers. For many, political participation now originates from the keyboard. With the rise of "point and click" activism and the ease of electronic communication, a new breed of online activism has reshaped representative democracy between elected officials and their constituencies. ${ }^{1}$ As this grassroots digital movement continues to swell, however, activists must work proactively with government to create spaces that enhance deliberation and public information. If they The ideal route for this collaboration would be for government entities to build public forum designated spaces into existing infrastructures of publicly administered websites, such as municipal and local government websites (e.g., www.cityofoakland.gov) or elected officials' homepages (e.g., www.senate.gov/feinstein).

The impetus for creating these new types of websites is driven by the lack of this type of comprehensive public online space. Although early scholars argued that the Internet as a whole is one large public space, over time, cyberspace has devolved into a collection of individual voices speaking to various, like-minded audiences without a definitive centralized central space. ${ }^{2}$ A simple Google search can reveal a voluminous return of

Copyright $(\mathcal{O} 2006$ California Law Review, Inc. California Law Review, Inc. (CLR) is a California nonprofit corporation. CLR and the authors are solely responsible for the eontent of their publications.

$\dagger \quad$ J.D., School of Law, University of California, Berkeley (Boalt Hall), 2006; B.A. Douglass College, Rutgers University 2000. I would like to thank Professor Molly Van Houweling for her guidance and invaluable comments on earlier drafts of this piece; Megan Lorenz for her encouragement, support, and rock star editing skills; and the rest of the editorial staff of the California Law Review for their meticulous editing and constructive feedback.

1. "Capitol Advantage is the nation's pioneer and premier provider of online and offline grassroots solutions for more than 1,500 corporations, nonprofits, associations, educational institutions, media portals, and other organizations. Our family of companies is nationally recognized for helping citizens make their voices heard, from the school house to the White House, from Main Street to Wall Street." Capitol Advantage, What We Do, www.capitoladvantage.com/what-we-do.html (last visited Oct. 30, 2006).

2. See Beth Simone Noveck, Designing Deliberative Democracy in Cyberspace: The Role of the CyberLawyer, 9 B.U. J. SCI. \& TECH. L. 1, 26 (2003) ("There is no such thing happening upon the 
political interests or opinions. Yet even with popular, high-traffic websites, the choir may be singing to itself because its participants have not garnered the credibility or reputation as a dependable political source or attracted those in the position to make tangible political change. Consequently, meaningful political dialogue on issues of public concern is relegated to individual, non-centralized websites where there is little chance of mutual dialogue between elected official and citizen. An online public space would ultimately bring these separated communities together and enable them to have a neutral and controlled environment-akin to a city council meeting - to participate in the democratic process. Officials and citizens alike could rely on this centrally designated and equally accessible space to speak and listen to local, state, and national concerns.

In addition to this practical disconnection, none of these popular political spaces offer First Amendment protection to their visitors. As a result of Congress's decision to allocate substantial regulatory power to private interests, web users are vulnerable to content-based discrimination or unequal access by URL administrators. ${ }^{3}$ Each private URL owner controls the traffic on his or her website, therefore limiting the application of the First Amendment to the site. Although a website author may choose not to censor postings on her blog or remove discussion threads on his bulletin board, each URL owner retains the right to do so as a private actor. ${ }^{4}$ If, for example, an ardent supporter of the war in Iraq was kicked off a public discussion board hosted by MoveOn.org after posting inflammatory pro-war sentiments, she would not be able to claim that the First Amendment should protect her online speech. Consequently, as scholars note, there is no public forum space online.

This state of affairs, however, does not imply that there cannot or should not be any public forum space on the Internet or that we should be satisfied with the spaces created by private interests that may (or may not) offer some First Amendment protection for speech. As the Supreme Court stated in Carey v. Brown, " [ $[\mathrm{t}]$ he maintenance of the opportunity for free political discussion to the end that government may be responsive to the will of the people and that changes may be obtained by lawful means, an opportunity essential to the security of the Republic, is a fundamental principle of our constitutional system.",5

For a truly progressive and representative model of democracy to thrive and move with technology, government entities must take advantage

public square. Those who know who you are and where to find you will come, but gathering points akin to New York's Central Park do not exist.").

3. Communications Decency Act of 1996, Pub. L. No. 104-104, 110 Stat. 133 (codified as amended at 47 U.S.C. $\$ 230(2000)$ ); see infra Part I.B.

4. See Dawn Nunziato, The Death of the Public Forum in Cyberspace, 20 Berkeley TeCH. L.J. 1 I I5, 1116-17 (2005).

5. 447 U.S. 455,467 (1980) (quoting Stromberg v. California, 283 U.S. 359, 369 (1931)). 
of the Internet as a new medium for political discussion and civic activism by creating government-sponsored public space online. Rather than maintaining the current free-for-all, where public speakers are left to assert a right of access to existing websites, it would be more beneficial if governments could devote parts of their websites to public forum space for open communication between citizens and representatives. Online public forums would become mutually reliable and legitimate spaces that citizens and representatives alike recognize as a center for democratic participation similar to real-space, publicly-administered democratic processes. Over time, these online forums can gain the level of credibility such that a government official would not disregard an online demonstration of their constituents on the virtual steps of the Capitol. Therefore, public speech advocates must work with government entities to create and make these online spaces available for First Amendment online activity in order to realize the opportunities for participatory and representative democracy on the Internet.

My vision for these online public forum spaces would involve developing centralized, state-sponsored property that protects First Amendment expression. ${ }^{6}$ These spaces would reinvigorate traditional Hague-ian notions of political speech by creating space "held in trust for the use of the public . . . for purposes of assembly, communicating thoughts between citizens, and discussing public questions" "by acting as comprehensive sites, mutually recognized as central political spaces by both citizen and elected official. ${ }^{8}$ Government entities would aspire to support and sustain central online spaces that host online rallies on virtual Capitol steps, house petitions to representatives, and establish joint communication between government officials and public citizens. In a technical sense, I am advocating for the formation of state-sponsored websites that are held to rigorous constitutional standards. These websites-with potential domain names such as www.townhall.gov, www.ca.state.gov/capitolsteps, and www.ci.berkeley.ca.us/publicforumwould be extensions of the state and provide public space for protected free speech under the First Amendment.

In Part I of this Comment, I discuss how the Internet has become the new center for political speech. Despite the popular shift to using cyberspace for political purposes, the Internet retains some serious structural impediments to democratic participation that could be remedied if government entities created designated, central websites. In Part II, I

6. For a scholarly examination of the compelling private interests to provide public online space, see, e.g., Nunziato, supra note 4.

7. Hague v. Cong. of Indus. Org., 307 U.S. 496, 515 (1939). For a more in-depth discussion of Hague and its significance, see Part lV, infra.

8. For a discussion of my vision for these websites, see Part IV, infra. 
examine how the Supreme Court has applied free speech principles to the Internet and compare this to how courts protect non-Internet public spaces through

public forum doctrine. I further argue that traditional public forum doctrine is unhelpful for protecting non-traditional spaces like the Internet when raised in the context of a right of access challenge to seemingly government property. To illustrate this problem, I discuss a case from the United States Court of Appeals for the Sixth Circuit involving a municipal website to advance the idea that online public forum spaces can protect free speech, but must be done through a collaborative effort as opposed to an aggressive or adversarial one. Therefore, I use Part III to provide a practical roadmap that public speech advocates and government entities can refer to in creating First Amendment-protected online public spaces. As part of this section, I also provide a mock-up sample version of my vision for an online public forum space. Finally, in Part IV, I consider any remaining statutory implications that may arise in building online public forum spaces, specifically focusing on California's Brown Act and Sunshine Laws.

Failing to expand our constitutional protections for public speech to online spaces compromises our capacity for participatory democracy and brings the legitimacy of government institutions into question. ${ }^{9}$ Compared with the time we spend online in privatized websites, our lack of public online space "reinforces passivity and the disconnection between citizenship and power." If If we continuously only use the Internet for shopping and research, then we forsake a potentially valuable use. This comment emphasizes how our current outlets for online political communication are inadequate because they perpetuate disengagement and disconnection. Yet, even though scholars are quick to assert that there are no public spaces online, ${ }^{11}$ it is still possible to create such spaces. By enabling comprehensive public forum spaces online, the Internet can foster broad political dialogue with online speech constituting "more than selfexpression; it [can be] the essence of self-government." 12

9. Noveck, supra note 2 , at 10.

10. Id.

11. See Noveck, supra note 2, at 25 ("[T]he Public Forum Doctrine cannot be applied in cyberspace because there is no public space. It is a private domain. There are no government lands and no public structures. Even the telecommunications infrastructure on which the World Wide Wcb rests is largely in private hands."). Early commentators, however, envisioned the Internet as one large public forum. See, e.g., David Goldstone, The Public Forum Doctrine in the Age of the Information Superhighway, 46 HASTINGs L.J. 335 (1995).

12. Red Lion Broad. Co. v. FCC, 395 U.S. 367, 390 (1969) (quoting Garrison v. Louisiana, 379 U.S. 64, 74-75 (1964)). 
I

\section{The New Speakers' Corner? Political Speech in Cyberspace}

\section{A. Online Activism: The Point-and-Click Movement}

In the last few years, the Internet has hosted an explosion of political organizing and democratic deliberation. A search for the word "political" on Technorati.com yields $2,575,803$ posts containing the word. ${ }^{13}$ In 2004 , the Internet became a central reckoning force for the Democratic and Republican presidential candidates: John F. Kerry and George W. Bush. According to the Pew Internet \& American Life Project, 75 million Americans used the Internet to read political news, discuss candidates, and directly participate in the political process. ${ }^{14}$ During the last two months of their campaigns, $81 \%$ of all American adults were contacted by those connected to the candidates - a quarter of this communication through email alone. ${ }^{15}$ In local politics, in 2002, the Pew Project reported that "Eighty-two percent of online local officials use email to communicate with citizens. Sixty percent do so at least weekly, and $21 \%$ do so every day."16 Finally, organizing-website MoveOn.org boasts that its political action committee raised \$1 I million dollars for eighty-one candidates in 2004 , and currently has 3.3 million online members. ${ }^{17}$ Right-wing blogger, Matt Drudge, maintains a daily tally on his website of visitors per day, month and year. As of May I9, 2006, 15:28 PST, 11,415,855 people visited his site in the past 24 hours, $28 \mathrm{I}, 148,285$ in the past 3 I days, and $3,601,276,999$ in the past year. ${ }^{18}$

In addition to this type of raw data, individuals and organizations flock online to create websites for posting rants, displaying artwork, and uploading original musical compositions on current events, ${ }^{19}$ presidential

13. Technorati.com, Technorati Search: Political, http://www.technorati.com/search/political (last visited May 19, 2006).

14. Pew Internet \& American life Project, The Internet and Campaign 2004 (2005), http://www.pewinternet.org/pdfs/PIP_2004_Campaign.pdf. According to the study, "52\% of internet users, or about 63 million people, said they went online to get news or information about the 2004 elections", " $35 \%$ of internet users, or about 43 million people, said they used email to discuss politics", and "11\% of internet users, or more than 13 million people, went online to engage directly in campaign activities such as donating money, volunteering, or learning about political events to attend." Id. at ii.

15. Id. at $\mathrm{I} 5$.

16. Pew lnternet \& American Life Project, Digital Town Hall: How local Officials Use the InTernet and the Civic Benefits They Cite from Dealing with Constituents ONL1NE (2002), http://www.pewinternet.org/PPF/r/74/report_display.asp.

17. See MoveOn.org, About the MoveOn Family of Organizations, http://www.moveon.org/ about.html (last visited May 19, 2006).

18. See Drudge Report, http://www.drudgereport.com/ (last visited May 19, 2006). "Right Wing News" places the Drudge Report at the top of its "Top 125 Political Websites." Right Wing News, The Top 125 Political Websites on the Net Version 4.0, http://www.rightwingnews.com/special/ pop125x2.php (last visited May 19, 2006).

19. See, e.g., Homepage of Michael Moore, http://miehaelmoore.com (last visited May 16, 2005) (website created by filmmaker and political enthusiast Michael Moore to critieize the Bush Administration). 
campaigns, ${ }^{20}$ and foreign policy. ${ }^{21}$ "Part deliberative town square, part raucous debating society, part research library, part instant news source, and part political comedy club, the internet connects voters to a wealth of content and commentary about politics."22 With the slightest grasp on forum technology, anyone can design interactive spaces such as bulletin boards, chats, and listservs in order to host large numbers of opinions (and jousts) between individuals who, potentially, will never exchange words in real space or face-to-face. The Internet now allows for web-based email conferences,${ }^{23}$ the gathering of signatures for online petitions, ${ }^{24}$ and virtual demonstrations, rallies and focus groups. ${ }^{25}$ Lively debate and political digressions often materialize on seemingly non-political websites, engaging communities that would not otherwise stumble into such conversations. ${ }^{26}$

Accordingly, online communication has reinvigorated the fundamental essence of the First Amendment, namely the freedom to express one's political beliefs. Political speech and deliberation is especially significant, as the Court noted in the landmark case, Hague $v$. Congress of Industrial Organizations: "citizenship of the United States would be little better than a name if it did not carry with it the right to discuss national legislation and the benefits, advantages, and opportunities to accrue to citizens therefrom."27

20. See, e.g., KidsforKerry.org, http://www.kidsforkerry.org (last visited May 16, 2005) (website in support of John Kerry created by twelve-year-old llana Wexler).

21. See, e.g., Not in Our Name Project, http://www.notinourname.org (last visited May 16, 2005) (website of an organization created in response to the U.S. government's "war on terrorism" launched in the aftermath of Sept. 11, 2001).

22. PEw, supra note 14.

23. See, e.g., The Principles Project: A Project of 2020 Democrats, http://www.principlesproject.com (last visited Feb. 19, 2005) (a multi-stage six-week online discussion to help create a one-page Statement of Progressive Principles as a clear vision of a just society and a progressive politics).

24. See, e.g., Challenge John Yoo's Invitation to $\mathrm{UCl}$ as a Chancellor's Distinguished Fellow, http://www petitiononline.com/mod_perl/signed.cgi?yoo2705 (last visited Feb. 19, 2005) (an online petition to the chancellor of University of California-Irvine opposing an invitation to Professor John Yoo to speak on campus as a "Chancellor's Distinguished Fellow").

25. See, e.g., GOPUSA, Online Activist, http://www.gopusa.com/activist/ (last visited Feb. 19, 2005); GOPUSA, Online Rally for America, hrtp:/www.gopusa.com/rally/ (last visited Feb. 19, 2005).

26. See, e.g., Pearl Jam Message Pit, http://www.forums.pearljam.com (last visited May 17, 2005) (featuring a bulletin board entitled "A Moving Train" and deseribed as a place for "Politics, current events-reasoned debate and discussion-we can all learn something new."); RollingStone.com: News and Politics Archive, http://www.rollingstone.com/politics (last visited May 17, 2005) (featuring original articles, a blog, articles and links to organizations and other news resources).

27. Hague v. Cong. of Indus. Org., 307 U.S. 496, 513 (I939) (holding a city ordinance prohibiting public parades on public streets, highways, public parks or buildings without a permit void on its face and affirming the fundamental value of the right of the people to peacefully assemble and petition the government for a redress of grievances as implicit to republican government). $C f$. Stephen Gey, Reopening the Public Forum-From Sidewalks to Cyberspace, 58 OHIо ST. L.J. 1535, 1539 
As a result, First Amendment case law illustrates a deep, rich commitment to protecting expressive political activity such as leafleting, solicitation, and parading. ${ }^{28}$ ln the Internet context, mass emails have become the modern-day version of leafleting, with MoveOn.org serving as one of the best examples of the ability to harness a powerful online community. For instance, in a recent email campaign to "Help Fire Tom Delay," MoveOn.org activists coordinated a web-based education and advocacy campaign that informed their membership of Delay's record of alleged criminal offenses and featured a link to sign a MoveOn-sponsored online petition on its website. These virtual pamphlets were also selfperpetuating, as they allowed recipients to become speakers themselves by either directly forwarding MoveOn's original message to friendly supporters or using a "Tell Others!" featured link. ${ }^{29}$ MoveOn also gave recipients the option of directly contributing to their organization by clicking on a "Help Out!" button and taking donations online..$^{30}$

Online campaigns also breathe new possibilities into the First Amendment's notion of "the widest possible dissemination of information," especially in light of the financial expense and time investment required for political movements. ${ }^{31}$ Dick Morris, President of Vote.com, notes, "Entire campaigns, which now take weeks or months to unfold, will take place at the click of a mouse."32 Organizers rely on the fast and cheap communication made possible by the Internet and mobilize their base of citizens without labor-intensive, time-consuming, and often expensive phone calls and intricate mailings. ${ }^{33}$ Whereas organizations

(1998) ("Despite the strong pro-speech language for which Hague is now best known, it was not inevitable that the case would transform the Court's public forum jurisprudence.").

28. See Sec'y of State of Md. v. Joseph H. Munson Co., 467 U.S 947 (1984) (invalidating state statute regulating fundraising activities and solicitation by charitable organizations); Jamison $\mathrm{v}$. Texas, 318 U.S. 413,416 (1943) (reversing defendant's conviction for distributing handbills on city streets and holding that a city ordinance cannot prohibit a person's constitutional right to express her views in an orderly manner by handbills, literature, or the spoken word); Hague, 307 U.S. at 512-13; Schneider v. State, 308 U.S. 147, 160 (1939) (reversing convictions of defendants for distributing literature in the streets or other public places in violation of a municipal ordinance).

29. Email from Tom Matzzie, MoveOn PAC, to Stacey Schesser, Help Fire Tom Delay (Apr. 6, 2005, 15:56:08 PDT) (on file with author). Upon signing, activists receive an immediate follow-up thank-you letter from MoveOn pointing them to other resources and organizations joining the campaign against Tom Delay, as well as suggested text to forward to concerned friends.

30. Id. The power of online fundraising is especially vivid in the 2004 Presidential election cycle. See PEw, supra note 14, at Part I-1. “The Howard Dean campaign collected over $\$ 20$ million through the Internet, a remarkable $40 \%$ of its total receipts. The Kerry campaign amassed $\$ 82$ million of its $\$ 249$ million online (33\%), while the Bush campaign, which did not go at internet fundraising with the same intensity or success as did the Democrats, collected $\$ 14$ million of its $\$ 273$ million online (5\%). Much of this online money came in donations under $\$ 200$." Id.

31. Associated Press v. United States, 326 U.S. 1, 20 (1945).

32. Dick Morris, Symposium: Direct Democracy and the Internet, 34 LoY. L.A. L. REv. 1033, 1042-43 (2001).

33. Terrence Hackett, Grassroots.Org: The Internet Gives Political Activists a Worldwide Reach, But It's a Mixed Blessing, CHI. TR1B. MAG., June 29, 2003, at 19. 
sometimes spend upwards of $\$ 30,000$ for a targeted mailing aimed at a percentage of total voters, ${ }^{34}$ one email can target millions with zero cost for postage and instant delivery.

Physical separation-once a formidable barrier to uniting geographically distant speakers-is also not an issue with the Internet. Rather, any centralized website can serve as "home base" for a movement and provide the opportunity for community building. Organizers can also encourage those visiting their website to download posters and signs, leading to further communication and fundraising opportunities in real space. For example, conservative groups have capitalized on their website as a clearinghouse to sell signs in support of U.S. troops and to raise money to fund a billboard advertisement that read, "Dear Hollywood ... . Get the Picture. America Supports Bush."35

Therefore, as the point-and-click movement continues to gain momentum, the impetus to create comprehensive online spaces that provide a central mechanism to communicate with elected officials while protecting such online political speech is imperative. Given the shift to using the Internet as a vehicle for First Amendment expression and participation in the democratic process, we must be equally proactive in implementing legal safeguards to protect and promote public speech.

\section{B. Error! The First Amendment Does Not Protect Public Activism on Privately-Owned Websites}

The Supreme Court has been especially protective of both the right to free speech and the physical property spaces allotted for public speech (e.g. "Speaker's Corners"), with First Amendment jurisprudence striking down regulations that abridge or burden the right to use these public spaces. ${ }^{36}$ The Court recognizes both the value of public speech and the right to access the space to speak as inextricably tied to the enjoyment of one's First Amendment privileges. ${ }^{37}$

34. Morris, supra note 32, at 1042 (citing mailing expenses incurred for a community the size of Jackson, Mississippi).

35. Hackett, supra note 33, at 19.

36. See Schneider v. State, 308 U.S. at 162 ("[T]he purposc to keep the streets clean and of good appcarance is insufficient to justify an ordinance which prohibits a person rightfully on a public street from handing literature to one willing to receive it. Any burden imposed upon the city authorities in cleaning and caring for the streets as an indirect consequence of such distribution results from the constitutional protection of the freedom of speech and press."). Although the government can impose reasonable time, place and manner restrictions, "a municipality may not empower its licensing officials to roam essentially at will, dispensing or withholding permission to speak, assemble, picket, or parade, according to their own opinions regarding the potential effect of the activity in question on the 'welfare,' 'decency,' or 'morals' of the community." Shuttlesworth v. Birmingham, 394 U.S. 147, 153 (1969) (reversing a conviction for violation of a city ordinance that imposed an impermissible prior restraint on the right of assembly).

37. See Hague, 307 U.S. at 515-16. ("The privilege of a citizen of the United States to use the streets and parks for communication of views on national questions may be regulated in the interest of 
In many ways, cyberspace has become the modern embodiment of our public streets and parks in providing the space for speech. In the previous section, I discussed how activists seek out their base audience in organizing online campaigns. AIternatively, individual political activists can surf the Internet in search of information, activism opportunities, and chat rooms, with the web serving as a primary resource for researching and discussing pressing current issues.

However, herein lies a major problem with protecting online speech: the individual speaker has a weak First Amendment free speech claim with respect to these online private websites. To return to the earlier example, the pro-war, pro-George W. Bush supporter can post her speech on a MoveOn.org bulletin board or discussion board to capitalize on their higher web traffic. Yet in domg so, she runs the risk that her statements will be edited, censored, or removed if the content of her speech does not align with the website administrator's views. This First Amendment setback is the result of the Communications Decency Act of 1996 (CDA), in which Congress codified the privatization of the Internet by explicitly investing Internet Service Providers (ISPs) with responsibility to patrol their subscribers' online activity and devise their own restrictions for permissible speech of their subscribers. ${ }^{38}$

Professor Dawn Nunziato suggests that in taking a free market approach to Internet speech, Congress effectively yieIded power to "private Internet actors to do what it could not do itself-to restrict harmful, offensive, and otherwise undesirable speech, the expression of which would nonetheless be protected by the First Amendment." 39 In trading private-market control for First Amendment speech protection, the CDA effectively insulated ISPs from liability should they choose to restrict or censor expression that does not comply with their speech policies or terms of service. ${ }^{40}$ Therefore, even if some private websites provided a space for public speech - and significant public activity occurred in these spacesthey would still not have to adhere to the same standard of liability as a publicly sponsored website would have as a state actor. ${ }^{41}$ Furthermore,

\footnotetext{
all; it is not absolute, but relative, and must be exercised in subordination to the general comfort and convenience, and in consonance with peace and good order; but it must not, in the guise of regulation, be abridged or denied.").

38. See Communications Decency Act of 1996, Pub. L. No. 104-104, 110 Stat. 133 (codified as amended at 47 U.S.C. $\$ 230(2000)$ ).

39. Nunziato, supra note 4, at 1129 (citing 47 U.S.C. $\$ 230$ ("It is the policy of the United States ... to preserve the vibrant and competitive free market that presently exists for the Internet and other interactive computer services, unfettered by Federal or State regulation." Id.)).

40. Id. at 1129 .

41. Id. at 1130 ("[S] uch speech is only protected if at all by the grace of the private entities who control the private spaces in which such speech is hosted.").
} 
passage of the CDA allows the government to effectively extract itself from any obligation to provide publicly sponsored online space. ${ }^{42}$

The disturbing result of the CDA is that the majority of online spaces are privately-owned-as denoted by the ".com" and ".org" meta tagswith the expression contained within those spaces privately regulated. Through contractually imposed "Terms of Service," America Online (AOL), one of the largest Internet Service Providers, "enjoys unfettered discretion to censor constitutionally-protected speech in its discussion forums and other online spaces. ${ }^{, 43}$ Google, the largest search engine in the world, maintains a strict policy against hosting ads that contain "sensitive images" or "advocate against any individual, group, or organization" for both their website and for partner websites, including Ask Jeeves. ${ }^{44}$ In the political realm, privately owned petition websites, such as www.PetitionOnline.com ${ }^{45}$ or www.Petition-Them.com, ${ }^{46}$ merely manage petitions for online organizers, but reserve the right to make content-based rejections of petitions as well as relinquish responsibility for delivering them to the appropriate party. Even if MoveOn.org created a virtual town hall through their site-whether stand-alone or as a link within their own cyber-infrastructure (i.e., www.townhall.org or www.moveon.org/ townhall) - it would ostensibly still not possess the same First Amendment protection as government website property. A MoveOn administrator could deny or regulate both access and content with unchecked power. The consequence of government ceding control to private entities, therefore, has yielded even less protection for speech content and speaker access in cyberspace than in real space. ${ }^{47}$

The practical manifestation of no government-sponsored websites is that the existing online communication remains disjointed and unreliable.

42. Id. ("[T]oday's Internet is constituted by an amalgam of private forums within which constitutional protection for free expression is nonexistent-and Congress appears to have wanted it that way.").

43. Id. at 1121 (citing AOL.com, Agreement to Rules of User Conduct, http://www.aol.com/copyright/rules.html (last visited Mar. 6, 2005) ("America Online and its agents have the right at their sole discretion to remove any content that, in America Online's judgment, does not comply with the Rules of User Conduct or is otherwise harmful, objectionable, or inaccurate.")).

44. Nunziato, supra note 4, at II24 (citing Verne Kopytoff, Google's Ad Rule Complex, Controversial, S.F. Chron., Aug. 9, 2004).

45. PetitionOnline.com, Frequently Asked Questions http:/www.petitiononline.com/ petition_FAQ.html (last visited Mar. 9, 2005) ("At PetitionOnline.com, our policy is that delivery of petitions is at the discretion and by the hand of the petition authors, rather than us, the hosting service.").

46. Petition-THem.com, ABout Us, http://www.petitionthem.com/?sect=about (last visited Mar. 9,2005 ) (" $[W]$ e do reserve the right to refuse submissions for petitions arbitrarily. As a consequence there will always be a brief 'checking period' by our staff before any petition appears on the site.") (emphasis in original).

47. Cf. Pruneyard Shopping Center v. Robins, 447 U.S. 74 (1980) (affirming state supreme court ruling that state constitution protected speech and petitioning, reasonably exercised, in shopping centers even where the centers were privately owned). 
The lack of common public forum space accentuates the structural gaps in the current Internet landscape, leaving the potential for an online Speakers' Corner unfulfilled. If this landscape continues to be dominated by private interests, government-sponsored websites will lose an invaluable opportunity to interact with constituents. Private websites alone cannot serve as a neutral ground for civic engagement, especially if the reliability of the individual constituents' homepages are questionable and sometimes unnavigable. Moreover, the physical disconnection of these individual, private websites removes the potential for diversity of ideas found in real space city council meetings and other public forums. Presently, there is a no neutral, First Amendment-protected space available for activists and their opponents to exchange views and engage with one another and their political representatives.

On the flip side, without a commonly recognized website, there is little assurance that an elected official can easily navigate to politically mobilized websites, save the utility of links or email forwards. ${ }^{48}$ There is very little chance that they would happen by their constituent's blog posting on foreign policy or a reauthorization bill, when compared to the effectiveness of holding a rally in a real, centrally located space such as the steps of city hall or in the middle of a Council meeting. As Professor Beth Simone Noveck notes, "In cyberspace, it is less like crying oyez from the central marketplace and more like whispering in a labyrinth." political websites that do have a strong following, there is no assurance that surfing legislative assistants will loyally check the district gadfly's homepage. In the jockey for a domain name, political cybersquatting or domain name confusion can also subvert the accuracy of political communication..$^{50}$ This dis-connectivity in the labyrinth of the Internet also emphasizes another drawback: an individual or organization must invest a

48. See Gey, supra note 27, at 1626 ("Despite each person's ability to be his own broadcaster, a joeqpblogger.org will never attract the eyeballs of a cnn.com even if he can reach many more than with a broadside."); cf. Scott Rosenberg, Politics by Other Means, SAlon, Feb. 11, 2004, http://www.salon.com.

49. See Noveck, supra note 2, at 26.

50. For example, within the feminist community, there is the Feminist Majority Foundation's "www.feminist.org" and the unaffiliated, but also feminist "www.feminist.com." Although both are arguably feminist, each website and respective administrating organization has a separate board of directors, resources, and fundraising targets and sources. In another example, "www.prochoice.com" actually promotes adoption and deters abortion, posting "testimonies of women forced to have abortions." In contrast, "www.prochoice.org" is the homepage for the pro-choice National Abortion Federation, and advertises "unbiased factual information about abortion." See Feminist Majority Foundation, http://www feminist.org (last visited Aug. 15, 2006); Feminist.com, About Us, http:/www.feminist.com/about/whatis.html (last visited Aug. 15, 2006); National Abortion Federation, http://www.prochoice.org (last visited Aug. 15, 2006); Prochoice.com, http://www.prochoice.com/abort_legal.html (last visited Aug. 15, 2006) (antichoice website portraying itself as a prochoice website). 
large amount of resources and advertising to make her space effective enough to host a movement. ${ }^{51}$

Finally, legal scholars note that political activists may be disinclined to surf away from their virtual community simply because they do not want to interact or address their cyber-opponents, leaving online communities with very little internal dissent and self-criticism. Professor Elizabeth Garrett notes:

$[P]$ litically active Internet users participate in chat rooms that tend to reinforce, rather than challenge, their beliefs and opinions. Users segment into communities of like-minded people with the result that they are not exposed to a diversity of views. They do not have to confront convincing arguments on the other side of an issue and defend their own positions ... This effect of the structure of cyberspace may lead to a decline in the richness of political discourse and a narrowing of the perspective of our citizens. ${ }^{52}$

In this sense, online interaction heightens the self-imposed disconnection of adversaries: each activist sits at his or her computer, engaging with his or her screen, keyboard and mouse as opposed to another activist or opponent. Admittedly, even before the Internet's infusion into popular culture, individuals congregated with those who shared similar views, joined clubs based on common interests, and supported candidates and organizations that represented their political agendas. Community-specific separation remains a limitation in both real space and cyberspace, with online public forum spaces not necessarily actively altering this. The hope, however, is that with the fast pace and constant evolution of technology, Internet programs could challenge comfortable notions of community by creating cyber-sidewalks and street corners where activists can "bump" into one another. ${ }^{53}$ At the very least, as online public forum spaces gain greater momentum and importance, it will be to the detriment of political activists to let their adversaries' posts and comments remain unaddressed.

\section{Moving Beyond The Email-Activist Model}

Given the opportunity to overcome geographic barriers and connect individuals through the Internet, electronic communication must aspire to

51. See Paul Schwartz, Symposium, Vote.com and Internet Politics: a Comment on Dick Morris's Version of Internet Democracy, 34 LoY. L.A. L. REv. 1071, 1079 (2001).

52. Elizabeth Garrett, Symposium: Political Intermediaries and the Internet 'Revolution', 34 LOY. L.A. L. REV 1055, 1063 (2001).

53. See R. Johan Conrod, Linking Public Websites to the Public Forum, 87 VA. L. REv. 1007 (2001). Conrod argues that the uniquely expressive nature of links- "links-speech"-enables a revolutionary form of First Amendment protection, given their high compatibility with the normal activity of a website: "Web users may choose to avoid clicking on links that they perceive as controversial or contrary to their own views. Those who support, or are curious about, the views of a particular link, however, have full access to the content of a particular website. Thus, there is a virtually perfect demarcation between the willing and unwilling audience." Id. at 1036. 
meet the standards of in-person, real space interaction. Online public forum spaces should recognize their setbacks-time and space limitations of typing, failure to instantaneously observe human emotion and reactionand compensate with a comprehensive space that permits regulated interactions. Email, as the current and dominant method for political communication, illustrates an able, yet stilted attempt to substitute meaningful and adequate two-way interaction.

Email affords little opportunity for in-person interaction between legislator and citizen and often, the unilateral nature of email provides no mechanism for accountability. On the receiving end, standardized, en masse, and "cut-and-pasted" emails cloud the line between authentic and contrived communication. Jonathan Zittrain, co-director of Harvard Law School's Berkman Center for Internet and Society, says, "It can be difficult to tell the difference between grassroots and AstroTurf," when it comes to emails from constituents, with the result that emails are losing clout on Capitol Hill. ${ }^{54}$ Similarly, Professor Garrett notes:

Mass emails ... seldom reach the representative directly-unless the sender is a constituent with political clout-but instead go into some legislative correspondent's in-box and receive an automatic or form response. Representatives learn of the email campaign and get a tally of the votes for and against, and this information is relevant to policy decisions although it does not dictate them. ${ }^{55}$

To complicate matters further, the occasional personal email message often goes unnoticed as political staff become socialized to ignore the substance and content of messages bearing the disguising signal of a generic subject line.

However, Professor Garrett also notcs the value of email that should be translated into a comprehensive online public forum space. She writes:

Anecdotal evidence also suggests that the volume of substantive, individually written communications by constituents to representatives has increased because of the relative ease of email. Such individuated communications are typically given more weight by lawmakers ... may change the policy agenda somewhat and require legislators to respond with clearer positions on controversial issues. ${ }^{56}$

Garrett's theory on the volume of response of issues-a quantitative extraction from mass emails-impacts policy decisions and catalyzes responses from elected officials. The potential for generating a stir, then, must be considered when building a website, such as in housing a polling section where constituents can vote by survey. The crucial takeaway from

\footnotetext{
54. Hackett, supra note 33.

55. Garrett, supra note 52, at 1065.

56. Id. (emphasis added).
} 
Garrett's observation, however, is that electronic communication must offer constituents and officials alike the opportunity for substantive dialogue rather than just an en masse response.

Given both the high demand for online political engagement and the lack of designated space, there remains a void in the world of cyberactivism-where can citizens who want to participate in government go online to engage with their elected officials or other like-minded cyberactivists? Failure to meet this need has grave democratic implications. Online participation could have an overwhelming cultural impact on the nature of representative and direct democracy by directly connecting government to its constituencies. ${ }^{57}$ If democracy is best served by representing a broad-based group of speakers, public websites can provide greater opportunity for individuals to testify publicly at hearings or meetings and be heard on the official record. This would improve deliberation by allowing for more citizen input, as well as empower the individual who would never or could never go to a town meeting to participate. $^{58}$

Legislators and citizens alike can trust that a neutral website will yield formal and meaningful contributions to political debate. Given the reliance and relevance of online communication, there is the potential for any publicly maintained websites - such as a Iocal city's homepage, ${ }^{59}$ the Federal eRulemaking Portal, ${ }^{60}$ or even Senator Barbara Boxer's online office $^{61}$ - to host online public space, should government intend to create or designate these spaces.

Ultimately, the goal for this type of electronic communication is not to replace person-to-person, real space interaction with government officials but rather that political cyberadvocacy will supplement in-person visits, telephone calls, and handwritten letters. At the same time, digital communication will enable those who would never consider direct communication with their government in the first place. ${ }^{62}$ The fact that a third of Internet users claim that they have used email or the Internet to try

57. Noveck, supra note 2 , at 5 ("[I]n the same way that the design of a ballot can change the result of the election, more sophisticated communications technology can transform democratic political institutions, making them more participatory and deliberative."). Cf. Dan Hunter, Cyberspace as Place and the Tragedy of the Digital Anticommons, 91 CALIF. L. REv. 439 (2003) (opposing the eonceptualization of cyberspace as a "place," and saying that "propertizing" online spaces will lead to the "tragedy of the digital anticommons").

58. As Professor Sunstein notes, onc purpose for proteeting public forum space is ensuring that public facilities are used for equal access to largcr audiences, even if unwelcome or for the purposes of complaint. Cass Sunstein, Republic.COM 31 (2001).

59. See, e.g., City of Oakland-Official City Website, www.oaklandnet.com (last visited June $10,2006)$.

60. See, e.g., Regulations.gov, http://www.regulations.gov/due_today.cfm (last visited June 10, 2006).

6I. See, e.g., Barbara Boxer, www.boxer.senate.gov (last visited June 10, 2006).

62. See PEW, supra note 14. 
to change a government policy or sway a politician's vote suggests that providing this space would also harness the political activism of Internet users who feel disempowered and want more from the political process. ${ }^{63}$ Essentially, creating public space online will empower new voices within our democracy, thereby enhancing the representative process.

The challenge, however, is not in the creation of the space, but in preserving its purpose should users take advantage of it. First, there is Iegitimate concern that a government-sponsored space may go unused or fail to recruit a wide array of perspective. The local gadfly may very well dominate the listserv just as much as he dominates a city council meeting. The average citizen may not venture to these websites, or even know about their existence. However, as aforementioned, in 2002, "Eighty-two percent of online local officials use email to communicate with citizens. Sixty percent do so at least weekly, and $21 \%$ do so every day." ${ }^{\prime 64}$ Providing a public online website seems to be the next step in fostering this shift to electronic communication. In other words, if local officials are using email and normalizing its use, the citizen who wants better access to his or her representative has a greater power to respond and interact, beyond hitting a reply button.

The second challenge of convincing diverse traffic to enter the online space poses the same challenges as in real space. The appeal of attracting members of the Ku Klux Klan to a public website may be unnerving for some participants - why not let KKK members stay in the confines of their own cyberspace? On the flip side of this concern is that alreadydisenfranchised and silenced entities may feel even further marginalized given the high costs and learning curves associated with technology. Yet, tracking the demographics of users-by race, gender, age, and region - and highlighting the inequities of the digital divide ${ }^{65}$ may spur its own movement for equal access. Furthermore, observing an oppressive comment may spur dialogue and increase participation on public websites. The urge for dialogue and dissent may shift the comfort of preaching only to your respective cyber-choir to engaging with someone who has the power to act on your viewpoint. The current alternative of separated and isolated movements protected by the comfort of uniform reaction fails to

63. Id. at iii.

64. PEw, supra note 16.

65. Although relevant to this discussion, for a more comprehensive overview of the "digital divide," see Symposium, Bridging The Digital Divide, 20 CARDozo ArTS \& ENT. L.J. 1 (2002). Aecording to Wikipedia, the digital divide "results from the socio-economic differences between communities that in turn affects their access to digital information mainly but not exclusively through the Internet. Broadly speaking, the difference is not necessarily determined by the size or depth of the user group. Any digital media that different segments of society can use, can become the subject of a digital divide." Wikipedia, Digital Divide, http://en.wikipedia.org/wiki/Digital_divide (last visited June $10,2006)$. 
energize and push democracy away from stagnation and deters activists from working within the system to address current failures.

With respect to a normative critique-which may question whether a government-sponsored space would be an improvement over the status quo-providing access to a public space would equalize the posts of every commenter. Given the rise of banner advertisement and corporate sponsorship of popular websites, any constituent can remain independent to their viewpoint and not feel overshadowed by business interests in posting content. In other words, a government-sponsored space should feature Jane Smith's comment as prominently as it would a lobbyist from Microsoft or Yahoo!. If the Internet is hailed as a space that equalizes everyone's ability to speak, then a publie space should ensure that its access policy reflects this ideal. Ultimately, the purpose of establishing these neutral online spaces is to promote equal online access to public audiences and promote the influence of individuals against the overwhelming presence of privately-controlled websites.

II

\section{The Court's Response to Legalizing Public Speech in New Spaces}

In 1939, the U.S. Supreme Court decided Hague v. Congress of Industrial Organizations, a landmark case protecting the right of public assembly and freedom of speech and expression. ${ }^{66}$ At issue was a local ordinance, which prohibited public parade or assemblies without a permit. ${ }^{67}$ Respondent, a labor union, claimed that the ordinance was void on its face for forbidding any person to "distribute or cause to be distributed or strewn about any street or public place any newspapers, paper, periodical, book, magazine, circular, card or pamphlet," under the First Amendment. ${ }^{68}$ In addition, respondents also claimed that city officials discriminated against them by prohibiting and interfering with distribution of their leaflets and pamphlets while permitting others to distribute similar printed matter. ${ }^{69}$

The District Court found that the labor union's actions, including collective bargaining and organizing unorganized works, was lawful and that petitioners used their official capacity to adopt and enforce a discriminatory policy against petitioners. ${ }^{70}$ Furthermore, the court found that respondents "interfered with [the union's] right of passage upon the streets and access to the parks of the city; that these ends have been accomplished by force and violence despite the fact that the persons

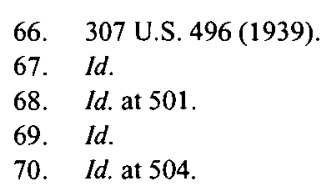


affected were acting in an orderly and peaceful manner," and that this exclusion was done without authority of the law or a proper judicial hearing. ${ }^{71}$ The court also found that petitioners adopted and enforced a policy that deliberately discriminated against respondents, even though the respondents distributed information that was "not offensive to public morals, and did not advocate unlawful conduct . . . and that their distribution was being carried out in a way consistent with public order and without molestation of individuals or misuse or littering of the streets."72 The Circuit Court of Appeals concurred in the trial court's finding of fact and affirmed. ${ }^{73}$

In reviewing the lower court's analysis of the ordinance, the Supreme Court connected the use of property and space to the exercise of free assembly and speech:

Wherever the title of streets and parks may rest, they have immemorially been held in trust for the use of the public and, time out of mind, have been used for purposes of assembly, communicating thoughts between citizens, and discussing public questions. Such use of the streets and public places has, from ancient times, been a part of the privileges, immunities, rights, and liberties of citizens. ${ }^{74}$

The court also noted the privilege to exercise free speech is not absolute and may be regulated for the purposes of peace and good order, within the confines of protecting constitutional rights. ${ }^{75}$ The court held that the ordinance's absolute prohibition on distribution of circulars, handbills, and placards was void. ${ }^{76}$

The relevance of Hague is complicated when comparing real space to cyberspace. On one hand, the public controls a substantial amount of the Internet and use it for many of the same purposes as they once used the streets and parks - to assemble, communicate, and discuss. As Justice Kennedy discussed in the context of regulating public speech with respect to cable channels:

Minds are not changed in the streets and parks as they once were. To an increasing degree, the more significant interchanges of ideas and shaping of public consciousness occur in mass and electronic media. The extent of public entitlement to participate in those

71. Id. at 504-05.

72. Hague, 307 U.S. at 505.

73. Id. at 506.

74. Id at 515-16.

75. Id. at 516. "[U]ncontrolled official suppression of the privilege cannot be made a substitute for the duty to maintain order in connection with the exercise of the right." Id.

76. Id. at 518 
means of communication may need to be changed as technologies change. ${ }^{77}$

Kennedy's quote evokes memories of what the Hague court sought to protect in applying the First Amendment to common parks and sidewalks, translating this older analogy into one that is adaptive of modern communication styles. However, the gap between Kennedy's observation and the structural landscape of the Internet is that there are no "parks" or "streets" in cyberspace-there are no thoroughfares, no town centers, no places where you can stumble by and see the labor union passing out their leaflets or organizing the unorganized. The Internet is self-driven, selfGoogled, self-determined, and although this is part of the value of cyberspace, it effectively isolates each of us. Hopefully, Kennedy's words will serve as the spark that will later protect spaces that sustain our democracy in the form of virtual public spaces.

In 1997, the Court had its first opportunity to consider the application of the First Amendment to cyberspace in Reno $v . A C L U{ }^{78}$ a case challenging two provisions of the Communications Decency Act, which sought to protect minors from harmful material on the Internet. ${ }^{79}$ The Court held that these provisions abridged speech protected by the First Amendment and struck them down on grounds of vagueness and overbreadth. ${ }^{80}$ Like Kennedy's quote above, Reno's language reveals the Court's willingness to recognize the Internet's potential as a new forum for public speech and free expression. ${ }^{81}$ Specifically, the Court writes, "through the use of chat rooms, any person with a phone line can become a town crier with a voice that resonates farther than it could from any soapbox. Through the use of Web pages, mail exploders, and newsgroups, the same individual can become a pamphleteer." ${ }^{82}$ Fortunately, this dicta again reflects the Court's capacity to envision the Internet as a vehicle to foster participatory democracy and lays a legal foundation for protecting a government-sponsored website as a new space for speech.

77. Denver Area Educ. Telecomm. Consortium, Inc. v. FCC, 518 U.S. 727 (1996) (Kennedy, J., concurring) (challenging provisions of the Cable Television Consumer Protection and Competition Act under the First Amendment).

78. 521 U.S. 844 (1997).

79. The two sections at issue were $\S 223(\mathrm{a})(1)$, which criminalized a knowing transmission of obscene messages to minors, and $\S 223$ (d), which prohibited a knowing display or sending of messages to minors that depicts or describes "patently offensive" (sexual) material, as measured by contemporary community standards. 47 U.S.C.A. \$ 223 (1997).

80. Reno, 521 U.S at 844,849 . The court declined to decide whether there was a Fifth Amendment issue involved.

81. See Hunter, supra note 57, at 490-9I; Gey, supra note 27 , at 1610-18.

82. Reno, 52 I U.S. at 869. 


\section{A. Protecting Public Speech in Real Space: The Public Forum Doctrine}

The avenue by which the Court historically protects both the presence of public speech and the right to access these spaces has been through public forum doctrine, which creates an individual's "positive right for venting unpopular views and conducting public debate in designated protected spaces." 83 Although public forum doctrine is aimed at protecting and enhancing a right of access for public speech, the Court has been reluctant to extend such measures to unconventional spaces. Rather, the Court has manipulated doctrinal terminology to uphold restrictions on public speech.

In a non-lnternet context, the Supreme Court devised the public forum framework for categorizing public space. ${ }^{84}$ This doctrine consists of threetiers of public property: "traditional," "limited," and "nonpublic." "Traditional" public forums are the quintessential spaces that serve as centers for public speech and assembly including public streets, sidewalks and parks. ${ }^{85}$ The Court was unwilling to confer this heightened status beyond places "immemorially .. . held in trust for the use of the public and, time out of mind ... . for purposes of assembly, communicating thoughts between citizens, and discussing public questions."

Thus, even if new forums bear the same qualities as "traditional" public spaces, the Court has refused to extend this high level of protection past the historic confines of the doctrine ${ }^{87}$ Therefore, "by definition a new sidewalk will not have been 'a traditional site for expressive conduct"" 88 and will not receive the same protection as a traditional public forum would. Even though the lnternet fits into this "traditional" definition and provides an effective space for those who could not otherwise be heard, ${ }^{89}$ the Court's strict interpretation indicates that it will most likely not extend traditional public forum status to such a new medium for communication.

\footnotetext{
83. Noveck, supra note 2, at 23.

84. Perry Educ. Ass'n v. Perry Local Educators' Ass'n, 460 U.S. 37 (1983).

85. Id. at $45-46$.

86. Hague v. Cong. of Indus. Org., 307 U.S. 496, 515 (1939)

87. However, the court notes that this privilege is "not absolute, but relative, and must bc exercised in subordination to the general comfort and convenience, and in consonance with peace and good order; but it must not, in the guise of regulation, be abridged or denied." Id. at 516.

88. Gey, supra note 27, at 1554 (citing Chad v. City of Fort Lauderdale, 861 F. Supp. 1057, 106I (S.D. Fla. 1994) (The district court noted, "[t]he sidewalk is new and small; it does not even extend the full length of the beach. It was created to accommodate traffic to and from the beach and, only having been built two years ago, has not been a traditional site for expressive conduct.")).

89. See Sunstein, supra note 58, at 28 ("[A] distinctive feature is that the public forum doctrine creates a right, not to avoid governmentally imposed penalties on speech, but to ensure government subsidies of speech. There is no question that taxpayers are required to support the expressive activity that, under the public forum doctrine, must be permitted on the streets and parks .... Thus the public forum represents one area of law in which the right to free speech demands a public subsidy to speakers.").
} 
The second category, limited public forums-also known as designated public forums-are reserved for public property that the state intentionally opens for the public to use for the purposes of expressive activity. ${ }^{90}$ Although the state is not required to open this forum to the public, once it does so, it is bound by strict scrutiny analysis and may exclude speakers only where such exclusion is necessary to serve a compelling state interest. Further, the exclusion must be drawn to achieve that interest. ${ }^{91}$

Thus, if certain individuals are prohibited from expressing themselves in the forum based on content or viewpoint, courts will not uphold these restrictions under an equal protection analysis, ${ }^{92}$ which maintains a "presumption of the equality of ideas," meaning that the government must not favor one message over another. ${ }^{93}$ However, with limited public forums, the court focuses entirely on the function for which the government intended the property to be used, as well as its compatibility with the expressive activity. ${ }^{94}$ For example, there is no right of access to a utility pole as a public forum for political signage because "the character of the property at issue" indicates that the government did not intend to use this property for expressive purposes. ${ }^{95}$ Hence, the dispositive issue for protecting public speech in this space is whether the government designates the space to be used for public speech and expression, as opposed to the manner in which citizens use the space.

Finally, the nonpublic forums are those public spaces that do not fit into either classification and, thus, the state may regulate the property no less than a private landowner with the power to reasonably restrict access on the basis of subject matter and speaker identity so long as such determinations are viewpoint neutral. ${ }^{96}$ However, the line between the designated public forum and the nonpublic forum are very blurry, leaving

90. Perry Educ. Ass'n v. Perry Local Educators' Ass'n, 460 U.S. 37, 45 (1983).

91. Comelius v. NAACP Legal Def. \& Educ. Fund, 473 U.S. 788, 800 (1985).

92. Police Dep't of the City of Chicago v. Mosley, 408 U.S. 92 (1972).

93. Laurence H. Tribe, american Constitutional. Law 940 (2d ed. 1988). In Mosley, the court enjoined a city ordinance prohibiting picketing within 150 feet of a school during school hours because it excluded "peaceful picketing of any school involved in a labor dispute." 408 U.S. at 92 . The court wrote the city "may not select which issues are worth discussing or debating in public facilities" and therefore, could not discriminate among pickets based on the content of their message. Id. at 95-96.

94. See Heffron v. Int'l Soc'y for Krishna Consciousness, 452 U.S. 640 (1981) (upholding a state rule restricting the sale or distribution of information occurring on state fairgrounds as a valid time, place, and manner restriction); Cornelius, 473 U.S. at 788 (upholding an order excluding organizations engaging in advocacy from participating in an annual charity fundraising drive targeting federal employees).

95. City Council of Los Angeles v. Taxpayers for Vincent, 466 U.S. 789, 813 (1983) (citing Perry, 460 U.S. at 44$)$.

96. See Perry, 460 U.S. at 49; see also Adderly v. Florida, 385 U.S. 39, 47 (1966) (holding that arrest and conviction of student demonstrators for violating a Florida statute did not deprive students of their constitutional rights to freedom of speech, press, assembly, or petition). 
more and more public spaces vulnerable to lower scrutiny and reasonable restrictions. Furthermore, when the government provides substantial and open alternative channels for the same communication, restrictions are likely to be considered reasonable. ${ }^{97}$ For example, a school's internal mail facilities were deemed a nonpublic forum since there was no indication "that the school mailboxes and interschool delivery system are open for use by the general public." 98 The policy of providing exclusive access to the selected bargaining representative for teachers was also reasonable because it was wholly consistent with the District's "legitimate interest in 'preserv[ing] the property ... for the use to which it was lawfully dedicated."

As a result of this framework, scholars have observed that the combination of carefully-constructed restrictions armed with a wellarticulated policy of compatible expression has limited the amount of space available for First Amendment speech. ${ }^{100}$ The substantive underpinnings of public forum doctrine's theory-protecting space for those who lack access, government subsidized space for expression, or equal opportunity to participate in government deliberation-is now subverted by a rigid preoccupation with the government's intention for the property. ${ }^{101}$ Under the regime, government retains full power to extinguish expressive potential by simply defining a policy that regulates the property with narrow terms and specific time, place, and manner restrictions, leaving a doctrine that holds very little force for those asserting a claim to access it. The court also ensures the ultimate escape door for government to avoid open access or First Amendment liability: close the forum entirely. ${ }^{102}$

Ultimately, this doctrine leaves few options for citizens to create or protect public space and suggests that a citizen trying to assert a right of access over non-traditional forum spaces will not succeed in protecting speech in this seemingly-public space even if the expression fits with a First Amendment activity.

97. Perry, 460 U.S. at 53 (suggesting that bulletin boards, meeting facilities and the United States mail were "substantial alternative channels that remain[ed] open for union-teacher communication to take place").

98. Id. at 47

99. Id. at 50-54.

100. See Gey, supra note 27 , at 1541 . ("These concessions have no natural limit, and at times the Court has described the permissible rationales for regulating the public forum so broadly that the regulatory exceptions could easily swallow the freedom whole.").

101. See TribE, supra note 93, at 987.

102. See Arkansas Educ. Television Comm'n v. Forbes, 523 U.S. 666 (1998) (holding that debate was a nonpublic forum and thus broadcaster could exclude a candidate in a reasonable, viewpointneutral exercise of journalistic discretion). 
B. A Citizen's Claim to Cyberspace:

\section{Why Public Forum Doctrine is Unhelpful for a Right of Access Claim}

There are two avenues for creating online space that require First Amendment standards of protection. The first method is for citizens to assert a right of access to publicly sponsored cyber-property since the "whole point of the public forum doctrine is that citizen speech on government property can be protected." 103 For example, scholars like Cass Sunstein note that public forum doctrine creates this distinctive right of access to public space. ${ }^{104}$

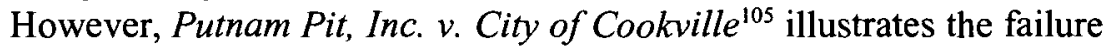
of this strategy. There, petitioner Davidian was the owner and editor of a website that published information concerning government corruption in the City of Cookeville. ${ }^{106}$ In addition to requests for computer files from the city, petitioner also requested that the city provide a hyperlink to Davidian's site on its own website. The city denied all of his requests. ${ }^{107}$

On appeal, petitioner argued that the District Court erred in granting summary judgment for the City and that the City violated his First Amendment rights by refusing to establish a hypertext link to his website. $^{108}$ To support his claims, petitioner alleged that the city had established a designated public forum by allowing other organizations and groups to link to its site and that, even if the city had not designated such a forum, he was unconstitutionally discriminated against because of his viewpoint. ${ }^{109}$

Applying a public forum analysis, the court noted that the Internet is a recent technological development and therefore does not comport with the Hague-ian notion of "traditional" public forums. Echoing Reno's acknowledgement of the Internet's communicative potential and noting how aspects of cyberspace may fall within the scope of traditional public forum space, the court deferred to the historical limitations of this category. ${ }^{110}$ Furthermore, since the City's site and the desired hyperlink did not allow for "open communication or the free exchange of ideas between members of the public," Cookeville's website was not a traditional public forum. ${ }^{111}$

103. Conrod, supra note 53, at 1033.

104. See SunSTEIN, supra note 58 , at 28 ("Government is essentially obliged to allow speakers, whatever their views, to use public property to convey messages of their choosing."); see also Conrod, supra note 53.

105. 221 F.3d 834 (6th Cir. 2000).

106. Id. at 838 .

107. Id. at 839

108. Id.

109. Id. at $841-42$.

110. Id. at 843 (citing Arkansas Educ. Television Comm'n v. Forbes, 523 U.S. 666, 679 (1998)).

111. Putnam Pit, 1nc. v. City of Cookville, 221 F.3d 834, 843 (6th Cir. 2000). 
In next evaluating whether the City's website was a designated public forum, the court examined restrictions on accessing the property and whether these limitations are compatible with the intended purpose of the website. ${ }^{112}$ Specifically, the court looked at the City's stated policy with respect to its webpage and the nature of the site in concluding that it did not constitute a designated public forum. The Court found that the intended purpose of the website was merely to convey information to the reader about the City and thus the City did not intend to provide access to individuals' hyperlinks. ${ }^{113}$ Accordingly, the court concluded that the City's website was a nonpublic forum and that while the petitioner was not entitled to link to the website, the City could not deny him access on account of his viewpoint. ${ }^{14}$

Regarding Davidian's First Amendment claim, however, the court held that he raised a material issue of fact as to whether the City discriminated against him based on his viewpoint and remanded this aspect of his case. ${ }^{115}$ It is likely that the impetus for denying Davidian directlinked access to the City's site was also content-based: his website was haled as the "self-appointed eye on government corruption for the City of Cookeville." "116 Essentially, Davidian sought to do what activists do in real space-stand on public property and express one's belief about government either directly to the municipality or to those who might be interested in linking to his site.

What is unique about Putman Pit is that although the court was very careful to protect government property from incompatible expression or incongruent rights of access, ${ }^{117}$ they did not give the City unbridled discretion to disregard First Amendment constraints. Even though the court focused on the City's stated policy and the relevance of compatibility in determining whether the website was a public forum, the court limited the City's ability to regulate citizen speech to reasonable restrictions, excluding viewpoint discrimination. ${ }^{118}$ This holding reaffirms that the court will apply First Amendment standards to protect speech online.

\footnotetext{
112. Id. at 844 .

113. Id.

114. Id. at 846 .

115. Id

116. Id. at 838 .

117. See Perry Educ. Ass'n v. Perry Local Educators' Ass'n, 460 U.S. 37, 49 n.9 (1983). ("It will not do, however, to put aside the Court's decisions holding that not all public property is a public forum, or to dismiss Greer, Lehman, and Jones as decisions of limited scope involving 'unusual forums."); Lehman v. City of Shaker Heights, 418 U.S. 298, 304 (1973) ("Were we to hold to the contrary, display cases in public hospitals, libraries, office buildings, military compounds, and other public facilities immediately would become Hyde Parks open to every would-be pamphleteer and politician. This the Constitution does not require.").
}

118. Cf. AOL.com, supra note 43 . 
However, mere protection is not enough. Weak right-to-access claims do not foster the ideal type of public online space because they potentially yield highly restrictive forums. ${ }^{119}$ On the positive side, the court indicated that it would safeguard public speech on public websites if there was evidence of "open communication or the free exchange of ideas between members of the public." 120 Yet even if the Sixth Circuit is amenable to recognizing online spaces for public speech, the Supreme Court refuses to apply public forum doctrine to untraditional spaces. The Court is willing to extend designated public forum protection only if there is clear evidence of governmental intent to create such space.

For example, in United States $v$. American Library Association, the court reviewed the Children's Internet Protection Act (CIPA) ${ }^{121}$, which denies public libraries federal assistance to provide Internet access unless they install software to block images constituting obscenity or child pornography and further prevented minors from obtaining access to harmful material. ${ }^{122}$ The District Court applied public forum doctrine to acknowledge a right of access to public library computer terminals, and consequently, the Internet. ${ }^{123}$

The Supreme Court, however, held that public forum analysis was out of place in this matter. ${ }^{124}$ In first rejecting the notion that library computer terminals are traditional public forums given historical confines, ${ }^{125}$ the

119. In citing to Kennedy's coneurrence in Lee and the majority opinion in Reno, the court even suggests the possibility for extending "traditional" public forum status to the Internet, despite Putnam Pit's central holding and also notes that "aspeets of cyberspace may, in fact, fit into the public forum eategory." Putnam Pit, 22I F.3d at 843. Seholars note that Justice Kennedy is more responsive to expanding the scope of public forum cases to include modern conceptions and spaees for expressive activity. See Gey, supra note 27, at 1558 (citing Kennedy's concurrence in Lee and majority opinion in Rosenberger $v$. Rector and Visitors of the University of Virginia, 515 U.S. 819 (1995), where he suggests that there are flaws in the existing doctrine and provides a stronger framework for speakers in government places if the Court were to overnule the Perry classification.) Justice Kennedy is specifically concerned that the Court's First Amendment applications allow the government unlimited authority to restrict speech because a policy is conveniently created on the government's terms, as opposed to a more objective analysis based on the actual characteristics and uses of the property. See Int'1 Soc'y for Krishna Consciousness, Inc. v. Lee, 505 U.S. 672, 695 (1992) (Kennedy, J. concurring). Rather, Justice Kennedy suggests, "[i]f the objective, physical characteristics of the property at issue and the actual public aceess and uses that have been permitted by the government indicate that expressive activity would be appropriate and compatible with those uses, the property is a public forum." Id. at 698 .

120. Krishna, 505 U.S. at 698 . As one scholar notes, the court's reasoning is circular: the website fails to qualify as a traditional forum because it does not allow for "free exehange of ideas between members of the public," yet it did provide for the free exchange of ideas until the City refused to add more links to its page. See Conrod, supra note 53, at 1026.

121. Children's Internet Protection Act (CIPA), 114 Stat. 2763A-335.

I22. United States v. Am. Library Ass'n., Inc., 539 U.S. 194, 199 (2003) (citing 1 I4 Stat. 2763A-

$335)$.

123. Id. at 206 .

I24. Id. at 205 .

125. Id. at 205-06 ("First, this resource-which did not exist until quite recently-has not 'immemorially been held in trust for the use of the public and, time out of mind, . . been used for 
court also declined to recognize them as designated public forums, since the government did not "make an affirmative choice to open up its property for use as a public forum." 126 Instead, the Court maintained that:

Internet terminals are not acquired by a library in order to create a public forum for Web publishers to express themselves. Rather, a library provides such access for the same reasons it offers other library resources: to facilitate research, learning, and secreational pursuits by furnishing materials of requisite and appropriate quality. ... It is "no more than a technological extension of the book stack."127

The Supreme Court's approach reaffirms the lesson from Putnam Pit: pressuring government entities to recognize existing public property as public forum space will not succeed. The Court was especially willing to shield government from unintended public forum consequences: "[e]ven if appellees had proffered more persuasive evidence that public libraries intended to create a forum for speech by connecting to the Internet, we would hesitate to import 'the public forum doctrine ... wholesale into' the context of the Internet." 128 The Court's concern is that citizens will demand First Amendment protection over the entire public space, akin to designating the whole city hall building as a public forum, as opposed to the steps. ${ }^{129}$ Accordingly, taking such an aggressive approach might not be the most helpful for ensuring long-term access to meaningful public forum spaces online. Coupled with the reluctance of courts to extend public forum status to new spaces and the propensity for investing government with the power to act as a private property owner, citizen activists need to work with government to build strong online public forum space with fair time, place and manner distinctions. ${ }^{130}$

purposes of assembly, communication of thoughts between citizens, and discussing public questions."'); Krishna, 505 U.S. at 679.

126. Am. Library Ass' $n, 593$ U.S. at 205-06 (citing Cornelius, 473 U.S. at 802-03, and Perry, 460 U.S. at 45).

127. Id. at 207 (quoting S. REP. No. 106-141, at 7 (1999)).

128. Id. at 207 n.3 (citing Denver Area Educ. Telecomms. Consortium, lnc. v. FCC, 518 U.S. 727, 749 (1996) (opinion of Breyer, J.)).

129. See American Library Ass'n., Inc. v. United States, 201 F. Supp. 2d 401, 456 (E.D. Pa. 2002) ("Thus, in Cornelius, where the plaintiffs were legal defense and political advocacy groups seeking to participate in the Combined Federal Campaign charity drive, the Court held that the relevant forum, for First Amendment purposes, was not the entire federal workplace, but rather the charity drive itself. . . . Similarly, in Perry Education Association v. Perry Local Educators' Association . . . which addressed a union's right to access a public school's internal mail system and teachers' mailboxes, the Court identified the rclevant forum as the school's mail system, not the public school as a whole."). Nunziato also points out that "[p]roperty such as offices within government-owned buildings, states prisons and the like are not held open by the government for members of the public for expressive persons." Nunziato, supra note 4, at 1145. By analogy, this suggests that "gov" spaces are extensions of government office building space and would not receive First Amcndment protection as a public forum.

130. See Vincent, 466 U.S. at 794 n.31 ("At some point, the government's relationship to things under its domain and control is virtually idcntical to a private owner's property interest in the same 
III

\section{Virtually Hague: A Roadmap for Working Proactively With Government to Provide Online Public Forums}

The more strategic option for ensuring public space online is to work with governments proactively and help guide their website development towards allocating corners for speech. At a time when e-government initiatives are developing public websites, it is a prime opportunity to incorporate the lessons gleaned from the public forum cases and create central website space. ${ }^{131}$ With $93 \%$ of federal, state, and local government officials reporting that their agency or division maintained a Website, and $75 \%$ of those increasing their investment in information technology, ${ }^{132}$ this is an optimal time to design a roadmap for governments to incorporate public forum websites that provide an outlet for democratic participation and strong First Amendment protection.

On the government-side of public forum doctrine, state actors have a valid concern about proceeding given the risk of First Amendment liability when regulating public speech. Carefully interpreted, however, public forum doctrine can provide guidance for government entities to host workable public spaces without triggering unmanageable burdens. The key is to work with public website administrators to develop clear policy intentions that carefully delineate reasonable time, place and manner restrictions. Although this creates a definitive boundary between First Amendment protected space and non-protected space, it allows both government and activists alike to take affirmative steps to create, protect, and subsidize First Amendment activity on the Internet in the long run.

Public cyberspace areas can realize benefits distinct from real space without becoming an onerous task for public entities. In his American Library dissent, Justice Souter raises relevant criticisms of the majority's analogy of the computer terminals to a book stack and posits normative arguments in support of creating public space online. ${ }^{133}$ As Souter notes:

kinds of things, and in such circumstances, the State, 'no less than a private owner of property, has power to preserve the property under its control for the use to which it is lawfully dedicated."') (citing Adderly v. Florida, 385 U.S. 39, 47 (1966)); see also Arkansas Educ. Television Comm'n v. Forbes, 523 U.S. 666 (1998) (political debate broadcast held to be a nonpublic forum, and therefore, petitioner could exclude respondent if based on reasonable, viewpoint-neutral restrictions).

131. At the federal level, a 2001 research poll indicated that the American public envisions an egovernment that is more than just a hub for consolidating paperwork, but holds potential for giving citizens access to information and the power to hold government more accountable to its citizens. A majority of people was in favor of websites established by elected officials where the public can offer comments on legislation or monitor public hearings over the Internet. See COUNCIL FOR EXCELLENCE in Government, E-Government: The Next American Revolution 22, http:/www.excelgov.org/ usermedia/images/uploads/PDFs/bpnt4c.pdf.

132. Id. at 23 .

133. American Library, 539 U.S. at 237 (Souter, J., dissenting) ("[B]locking the Internet is merely blocking access purchased in its entirety .... The proper analogy therefore is . . to buying an encyclopedia and then cutting out pages with anything thought to be unsuitable for all adults."). 
There is only so much money and so much shelf space, and the necessity to choose some material and reject the rest justifies the effort to be selective with an eye to demand, quality, and the object of maintaining the library as a place of civilized enquiry by widely different sorts of people. ${ }^{134}$

This point translates well for providing spaces for public speech online. Providing real space public spaces can be expensive, require oversight or hired management, and deal with breaches of the peace. In the Internet context, interactive technology can facilitate meaningful dialogue between government and citizen and increase civic participation without the real space analogy of expanding the town hall or providing more chairs. Government, supporters and counter-protestors alike can access, visit, and interact without the fear of security threats, physical violence or disorder present in real space. ${ }^{135}$ There is also less of a justification for limitations on speech, since it is easier to moderate or administer electronic communication with reasonable time, place and manner restrictions for posting length and appropriate subject matter. As a result, publicly sponsored, centralized websites would help supplement real space democratic institutions without imposing burdensome costs.

Given the fact that the courts have devised an equation in analyzing public forum spaces, applying these requirements to online spaces will be virtually easy and intuitive. First, albeit a theoretical good fit, there is little hope that the courts will ever recognize online space as a traditional public forum. ${ }^{136}$ Therefore, the only way to obtain protection for public speech is as a designated public forum, which hinges on the government's intent to open up their website. As the court notes, "The government does not create a public forum by inaction or by permitting limited discourse, but only by intentionally opening a non-traditional forum for public discourse."137 Closely tied to this issue of intent is whether the court believes the

134. Id. at 236.

135. In Cox v. Louisiana, 3 I 8 U.S. 413 (I943), and in Grayned v. Rockford, 408 U.S. 104 (1972), the Court upheld the government's right to impose time, place and manner restrictions on speech. At the least, the Court upheld the government's interest in preventing "confusion from overlapping parades or processions, to secure convenient use of the streets by other travelers, and to minimize the risk of disorder." See Rockford, 408 U.S. at 115; Cox, 318 U.S. at 4I6. However, in cyberspace there is limited danger of competing parades or overlapping demonstrations, given the utility of links in designating different addresses for assembling. Permit systems and prior restraints on speech would not be at issue, since web administrators could also create new links and organize websites according to organizations and date of assembly. See Conrod, supra note 53, at 1007. Conrod suggests that "links on public websites should receive the highest level of protection possible within the forum analysis framework: recognition that the website is a public forum." Id.

136. See Putnam Pit, Inc. v. City of Cookville, 22I F.3d 834, 841-42 (6th Cir. 2000) (citing Arkansas Educ. Television Comm'n v. Forbes, 523 U.S. 666, 679 (1998)).

137. Cornelius v. NAACP Legal Def. \& Educ. Fund, 473 U.S. 788, 802 (1985) (emphasis added). 
expression is compatible with the space. ${ }^{138}$ This is reassuring for state actors because it suggests that public website administrators will retain greater control over their space. On the flip side, citizens will clearly understand that they have a right of access to public websites and public speech will have adequate constitutional safeguards.

In drawing a clear roadmap for government entities to create public forum space online, the first step would be a transparent articulation of the government's intention that this website be a public forum for political engagement and discussion. ${ }^{139}$ It must be clear that the government opened up this space for the purpose of providing a public website where free speech and expression are protected according to the First Amendment and without content-based restrictions. The relevance of a stated policy is crucial since the Court has indicated the inherent compatibility for posting speech and information on the Internet (as opposed to posting on a utility pole). Many government entities should consider drafting a clear statement of purpose or a "Terms of Service" declaring the space a public forum and protecting speakers from content-based discrimination (assuring speakers will not be removed for criticism). This policy could pop up in a separate window and require electronic assent and privacy authorization by the speaker/forum visitor-whether government official or public citizen. It would also be helpful to prominently feature the words "Public Forum" in both the URL name and on the header of each website page.

Second, access to this space should be "generally available to an entire class of speakers" 140 as opposed to granting permission to individual members and then allowing them authorization to use the site. In Putnam Pit, the Sixth Circuit used this test to hold that the City's website was a nonpublic forum, since the city reviewed on a case-by-case basis whether to accept a hyperlink from outside speakers. ${ }^{141}$ Accordingly, public website administrators must not restrict access based on speaker identity. The difference here is that a public forum must be available to everyone, much like an open city council meeting or capitol steps. It would not be a public forum if only city employees could participate, but it would be permissible to limit speakers to posting only about the city's new housing initiative.

138. See Gey, supra note 27 , at 1546 ("It became obvious during the 1970 s and early 1980 s that the Court's focus on notions of compatibility and context would give the government a powerful tool to limit speech on public property."). In Grayned, the Court wrote, "the crucial question is whether the manner of expression is basically incompatible with the normal activity of a particular place at a particular time." As a result, the court held that "noisy demonstrations that disrupt or are incompatible with normal school activities are obviously within the ordinance's reach." Grayned, 408 U.S. at 116, 120.

139. See Cornelius, 473 U.S. at 802

140. See United Food \& Commercial Workers Union, Local 1099 v. Southwest Ohio Reg'l Transit Auth., 163 F.3d 341, 352 (6th Cir. 1998); Putnam Pit, 221 F.3d at 843-44.

141. See Putnam Pit, 221 F.3d at 843-44. 
The next consideration in this roadmap is the nature of the website and whether certain expressive conduct is excluded because it is incompatible with the forum's purpose. ${ }^{142}$ In other words, does the website intend to merely convey information to visitors or is does it intend to allow participation and interaction between citizens and government? ${ }^{143}$ Namely, does the space allow for open communication or the free exchange of ideas between members of the public? ${ }^{144}$ For example, in July 2001 the Environmental Protection Agency hosted an electronic bulletin board where citizens could give direct input on a proposed regulation. ${ }^{145}$ First Amendment considerations were a concern for the EPA: "Due to legal concerns about violating participants' First Amendment rights, the EPA's General Counsel's office demanded that moderators be allowed only to set the tone of the discussion, offer technical support and monitor messages for obscene language. They would not be permitted to edit or remove postings regardless of relevance." 146 Accordingly, it is clear that the EPA intended that this bulletin board be a public forum space by allowing general public access without discriminating based on content or criticism.

Similarly, at the local level of government, cities and districts use the Internet to engage constituents in online discussions with elected officials. For example, in Federal Heights, Colorado, the city website encourages residents of Federal Heights to enter an online chat room and participate in a weekly scheduled chat with Mayor Dale Sparks. ${ }^{147}$ Anyone can create a username and password for present and future chatting, thereby suggesting that there is open (and secure) access. Chat members must agree to the Chat Guidelines (i.e., no profanity, please be patient with turn to chat with the Mayor and in anticipating his response), ${ }^{148}$ signifying reasonable time

142. See United Food \& Commercial Workers Union, 163 F.3d at 352.

143. See Putnam Pit, 221 F.3d at 844.

144. Cf. Putnam Pit, 221 F.3d at 844 ("[T]he purpose of the city's Web site was 'to publish, electronically, information to Intemet users about the benefits and opportunities afforded within the community to its citizens and visitors' which included 'messages from city officials; council meeting agendas, ... job opportunities in city government; information about building permits; property taxes and the like.' ... the structure of the forum, as established by Cookeville, does not allow free and open dialogue between users; it primarily serves to convey information to the reader. This structure is consistent with the city's stated goals for the Web site, and is a further indication that the forum in question should not be considered a designated public forum.").

145. Noveck, supra note 2, at 4, 51-52 (citing Thomas Beierle, DEMOCRACY ON-LINE: AN Evaluation of the National Dialogue on Public lnvolvement in EPa Decisions, Resources FOR THE FUTURE REPORT (2002), http:/www.rff.org/reports/PDF<uscore>files/democracyonline.pdf (analyzing the EPA online consultation experiment) and City Scan, City Scan Overview, http://www.city-scan.com (last visited Nov. 19, 2002).

146. Id. at 51 .

147. Federal Heights, Colorado Homepage, http://www.ci.federal-heights.co.us/index.html (last visited Mar. 3, 2005); see also Mike Frassinelli, Politicians Find Chart Rooms a Two-Edged Sword, Sept. 27, 2004, available at http://www.mayorzikas.com/news3.html (last visited Mar. 3, 2005).

148. Federal Heights Chat Room, Chat with the Mayor!, http://www.ci.federal-heights.co.us/ council/chat/index.html (last visited Mar. 3, 2005). 
and manner restrictions. Although unclear as to the administration of this chat-does the administrator have the power to deny access and on what grounds?-the expression that is occurring within this online space satisfies the requirements for a designated public forum.

Finally, reasonable time, place and manner restrictions will enable public entities to effectively and easily manage the public space without fearing liability. ${ }^{149}$ Restrictions will also ensure that users understand the purpose of the space as indicated through an electronic signature before entering. Public administrators could regulate length requirements for postings, akin to time limits at a city council meeting and equally monitored with character limits. ${ }^{150}$ Subject matter restrictions could narrow the topic of speech, such as "Community Development," "Crimes," or "Public

Education," for a local city or municipality. Bulletin boards or forums could provide posting space organized according to topic and allow visitors to directly post replies to one another. Similarly, the space would be able to accommodate online rallies and demonstrations through organized links and could not deny access to participants based on the content or focus. ${ }^{151}$ It is also reasonable to require speakers to accurately identify themselves without the use of an anonymous screen name.

A virtual "Steps of the Capitol" sidebar can simultaneously host links to rallies for both pro-choice and anti-choice protests. Organizers would be able to create their own website with a direct link to these "Steps" and mobilize constituencies to post responses and upload pictures demonstrating for their respective cause. Under a time restriction, these demonstrations would only run for certain defined periods (i.e., one week), then be deleted or removed. Under a manner restriction, organizers would also agree to stay within the realm of the First Amendment in their posting. ${ }^{152}$ There could also be a "Speaker's Corner" where individuals could enter chat rooms and engage with other speakers with varying points of view. Elected representatives could host blogs and citizens could have the opportunity to directly post, engage, and communicate. Petitions could be directly uploaded to representatives without any intermediary or content review. The site could also host a calendar for local evenis and upcoming civic activities. Most importantly, the communication would comport with the nature and intended purpose of the website and speakers would not

149. Perry Educ. Ass'n v. Perry Local Educators' Ass'n, 460 U.S. 37, 47 (1983) ("Reasonable time, place, and manner regulations are permissible, and a content-based prohibition must be narrowly drawn to effectuate a compelling state interest.").

150. Oakland City Council allows two minutes per speaker during open forum sessions.

151. See Cornelius, 473 U.S. at 800.

152. For an extreme example of protecting speech in public spaces, see Cohen v. California, 403 U.S. 15 (1971) (holding that conviction based on expletive printed on appellant's jacket was not constitutionally supportable). 
have to be concerned that their speech will be censored or access denied based on their identity or viewpoint.

The last crucial aspect for following this roadmap and creating an online public forum space is consistency in following and enforcing the policy, especially with regard to speech content issues. ${ }^{153}$ One of the main reasons in arguing for public space online is so citizens do not have to fear censorship or ejection from websites based on the content of their speech. In Putnam Pit, for example, the court noted that City's policy gave broad content discretion to city officials and raised the possibility of viewpoint discrimination when implementing its website policies. ${ }^{154}$ Similarly, the Mosley court noted that government "may not select which issues are worth discussing or debating in public facilities" and therefore, cannot discriminate based on the content of the speaker's message. ${ }^{155}$ Accordingly, public entities must be cautious when limiting speech online and not misconstrue this responsibility to "restrict speech in whatever way [the government] likes." 156 Following these recommendations, the ideal public forum online space would be a central, "one-stop-shop" for activism and civic engagement, and could be incorporated any federal, state, or local website.

153. See United Food \& Commercial Workers Union, Local 1099 v. Southwest Ohio Reg'l Transit Auth., 163 F.3d 341, 352, 353 (6th Cir. 1998) ("Were we to hold otherwise, the government could eircumvent what in practice amounts to open access simply by declaring its "intent" to designate its property a nonpublic forum in order to enable itself to suppress disfavored speech. We therefore must closely examine whether in practice [the public entity] has consistently enforced its written policy in order to satisfy ourselves that [the] stated policy represents its actual policy.").

154. See Putnam Pit, 221 F.3d at 845-46.

155. See Police Dep't of the City of Chicago v. Mosley, 408 U.S. 92, 95-96 (1972).

156. See id. (quoting Krishna, 505 U.S. at 687). 


\section{THE ONLINE PUBLIC FORUM FOR THE CITY OF NEW HAGUE}

THIS WEBSITE IS A PUELIC FORUM SPACE SPONSOREO BY THE FICTITIOUS CITY OF NEW HAGUE, AS A PUBLICLY-SPONSOREO WEBSITE, THIS FORUM ADVANCES PUBLIC FREE SPEECH ANO SERVES AS A CENTRAL MEETING PLACE FOR CITHENS ANO OFFICIALS ALIKE.

THURSOAY, AUGUST 31, 2006

\section{Proposed Redevelopment Plan}

The City of New Hague will be focusing on the Redevelopment Plan at the upooming City Council Meeting. Included in the discussion will be presentations by the Independent Business Owners Organization and the Affordable Housing Caalition. Proposals regarding the Redevelopment Plan for Rockwell Street will be reviewed and considered by the Council.

Anyone who wishes to speak or present information about the Redevelopment Plan can download the Plan here as well as submit their name to speak in person here or submit their online comment here.

Thank you.

POSTEO BY E"SECRETARY"> AT 11:50 AM

MONDAY, AUGUST 28, 2006

City Council Live Feed

At 8:00 p.m., the City of New Hague will hold its weekly City Council meeting. The Secretary of the Council will engage in live blogging of the meeting here and interested constituents can post their concerns and questions to council members here.

Please be advised that all submissions are limited to 500 words, may be pre-screened by the Secretary for the use of profane or obscene language, and must relate to the issue discussed at the time of submission. For those constituents interested in submitting their questions and concerns in advance of the meeting, the Secretary (secretary@newhague.gov) will accept early postings beginning at 7:00 p.m.

POSTEO BY \& SECRETARY* $>$ AT 8:30 PM
CITY LINKS

City of New Hague Mayor's Office

City Council

Board of Education

SPEAKER'S CORNER

Local Calendar: Upcoming Events! Today's Rally: Capitol Steps

Chat with Mayor Boone: RIGHT NOW!

Chat with Councilwoman Lorenz: Tues, 3:00 p.m.

New Hague Debates... Tax Increases

Submit a Question for the Upcoming City Council Meeting

PREVIOUS POSTS

Proposed Redevelopment Plan

City Council Live Feed

TERAS OF PARTICIPATIOH

New Hague's TPM Restrictions

Chatroom TPM Restrictions

Speaker's Corner TPM Restrictions

ARCHIVES

August 2006 
IV

\section{Navigating Statutory Law CONCERnS}

Finally, as public entities begin to embrace new technology and develop their websites, they might also be concerned about triggering statutory liability given the requirements of open meeting and sunshine laws. For example, compliance issues arise when considering how to initiate online public commentary or webcast legislative hearings and council meetings. Following the above roadmap for creating designated public forums is relevant for local and state governments as they implement reasonable time, place and manner restrictions and simultaneously preserve the spirit of open meeting laws.

The Ralph M. Brown Act of California is the most relevant statute for this discussion. ${ }^{157}$ The purpose of this law is to ensure that public officials take their actions openly and conduct open deliberations. ${ }^{158}$ The preamble of the Brown Act features a strong declaration of public policy that the "public commissions, boards and councils and other public agencies in this State exist to aid in the conduct of the people's business." 159 In interpreting section 54950, the California Supreme Court wrote that, "It declares the law's intent that deliberation as well as action occur openly and publicly ... Deliberation thus connotes not only collective discussion, but the collection acquisition and exchange of facts preliminary to the ultimate decision." 160 Specifically, "[a]ll meetings of the legislative body of a local agency shall be open and public, and all persons shall be permitted to attend any meeting of the legislative body of a local agency" except those provided as closed sessions. ${ }^{161}$

State and public entities should not be overwhelmed by this tendency towards openness because case law indicates that the same designated

157. CAL. Gov't CoDE $\$ 54950$ et seq. (2005).

158. In San Diego Union v. City Council of San Diego, 146 Cal. App. 3d 947, 955 (1983), the court concluded that it must eonstrue "the "sunshine law' liberally in favor of openness." "Sunshine law" refers to the sections on open meetings; here the court was stating that this section of the law must be liberally construed as opposed to the "personnel exception," which must be construed narrowly.

159. Cal. Gov't CODE $\S 54950$ (2005).

160. Sacramento Newspaper Guild v. Sacramento County Bd. of Supervisors, 263 Cal. App. 2d $41,47-48$ (1968) (holding that the trial court properly interpreted the Brown Act in entering a preliminary injunction to require that an Elks Club luncheon with members of the Sacramento County Board of Supervisors constituted a meeting open to the public). The court's rejection of narrow interpretation of open meetings was part of the aftermath of Watergate and subsequent concerns over secret government decision-making. In this decision, the court made clear that it was embracing the public's "inalienable right to be present and to be heard at all deliberations of governmental bodies wherein decisions affecting the public are bcing made." Id. at 49 (quoting Progress RePORT To Legislature, AsSEmbly INTERIM COM. ON Judiciary, at 21 (1953)).

161. CAL. GOV'T CODE $\S 54953$ (2005). The Act specifically affords the public the opportunity "to directly address the legislative body on any item of interest to the public," which includes the right to publicly criticize "the policies, procedures, programs or services of the agencies, or of the acts or omissions of the legislative body. CAL. GOV’t CODE $§ 54954.3$ (2005). 
public forum principles apply to sunshine law claims. ${ }^{162}$ Liability for "nonopenness" becomes a factor when government outright prohibits public presence or imposes content-based restrictions. For example, in a case brought under section 54954.3, the court applied public forum analysis to hold that the School Board meetings are limited public fora and the District Bylaws could not proscribe public commentary. ${ }^{163}$ The court also recognized the "public's fundamental right to engage in robust public discourse on school issues." 164 This suggests that the above roadmap is relevant at the local and state level and that statutory law will not force governments to structure technology beyond the limits of limited public forums.

Consequently, open meeting laws will permit public entities to impose reasonable time, place, and manner restrictions for online speech, such as posting limitations and disclosing speaker identity.

However, the court differs from California statutory law in that it uses much broader language to recognize the importance of public speech. For example, "public visibility breeds public awareness, which in turn fosters public activism politically and subtly encouraging the governmental entity to permit public participation in the discussion process." 165 Similarly, the court specifies that public meetings cannot be closed down to avoid First Amendment obligations because it would "deprive the public of the most appropriate forum to debate these issues." "166 Unlike federal courts, which rely heavily on the government's intention for the space and compatibility of expression, at the state level, there is arguably more room for protecting public speech in meetings. This is likely attributable to the fact that public meeting spaces are highly compatible with free speech, implying that there will be protection for analogous online spaces. Although this does not suggest that government is obligated to entertain every request to speak in ıneetings-since time, place, and manner restrictions still apply-it bodes well for developing online space for political participation.

ln this sense, then, the next logical extension for open meeting laws is to expand its scope to protect online broadcasts and other applications of technology that include public commentary for deliberation. For example, the scope of the Brown Act should also include online public testimony, use of the lnternet to post agenda items and recordation of meetings' ininutes, and even expanding to webcasting meetings and allowing online subınission of public testimony. ${ }^{167} \mathrm{~A}$ remaining question within this

\footnotetext{
162. See Levanthal v. Vista Unified School District, 973 F. Supp. 951 (S.D. Cal. 1997).

163. See id.

164. Id. at 960 .

165. See id. at 959 (quoting San Diego Union, 146 Cal. App. 3d at 955).

166. See id. at 961 .

167. California citizens can rely on section 54593 , which specifically includes a section allowing legislative bodies the use of teleconferencing in connection with meetings with the requirement that
} 
analysis is how much information governments would be compelled to post online and whether citizens could impose an affirmative obligation on government to keep pace with technology. Given the practical arguments against this type of accountability, however, it is more feasible that courts would not place public entities in such a vulnerable position.

\section{CONCLUSION}

With the rise of online political communication and increasing amount of "point-and-click" activism, the intersection of First Amendment jurisprudence and cyberspace law creates the impetus for government to designate cyberproperty to public speech and expression. The Supreme Court and one Court of Appeals have signaled the utility of dedicating online forum space-so long as it comports with traditional notions of public discussion and communication. Working with governments proactively, as opposed to asserting a right of access, will result in comprehensive public forum space online. Hopefully, establishing this new domain to access government will reinvigorate the public forum doctrine for new mediums of communication and ensure an interactive and responsive democracy. 
